\title{
HUBUNGAN MINAT DAN KEBIASAAN MEMBACA DENGAN \\ HASIL BELAJAR GEOGRAFI SISWA SMA UNGGULAN PONDOK \\ PESANTREN ZAINUL HASAN GENGGONG PROBOLINGGO
}

\author{
Kurnia Maulidi Noviantoro ${ }^{1}$, Achmad Amirudin ${ }^{2}$, Budijanto ${ }^{2}$ \\ Email: maulana.novianto@gmail.com, ach.amirudin.fis@um.ac.id, \\ budijanto.fis@um.ac.id
}

\begin{abstract}
Abstrak: Penelitian ini bertujuan untuk (1) mengungkap hubungan antara minat membaca dengan hasil belajar geografi, (2) mengungkap hubungan antara kebiasaan membaca dengan hasil belajar geografi, (3) mengungkap hubungan antara minat dan kebiasaan membaca dengan hasil belajar geografi, dan (4) mengungkap hubungan yang paling dominan antara minat dan kebiasaan membaca dengan hasil belajar geografi. Populasi penelitian adalah seluruh siswa kelas X SMA Unggulan Pondok Pesantren Zainul Hasan Genggong Probolinggo yang terbagi dalam empat kelas. Sampel penelitian dipilih dengan teknik purposive sampling dengan menunjuk dua kelas yang memiliki nilai ratarata tertinggi dan terendah yaitu siswa kelas X-3 untuk kelas nilai tertinggi dan siswa kelas X-4 untuk kelas terendah. Pengumpulan data dilakukan dengan instrument angket. Hasil belajar diukur dengan keberadaan nilai UAS semester ganjil siswa. Hasil penelitian menunjukkan bahwa (1) terdapat hubungan negatif antara minat membaca dan hasil belajar geografi dengan kontribusi minat membaca sebesar $8,8 \%$, (2) terdapat hubungan positif antara kebiasaan membaca dan hasil belajar geografi dengan kontribusi kebiasaan membaca sebesar $21,8 \%$, (3) terdapat hubungan yang positif secara simultan antara minat dan kebiasaan membaca dengan hasil belajar geografi, (4) Kebiasaan membaca memiliki hubungan yang paling dominan di antara minat membaca dengan hasil belajar geografi.
\end{abstract}

Keywords: minat membaca, kebiasaan membaca, hasil belajar.

\section{PENDAHULUAN}

Tinggi rendahnya minat baca sangat erat hubungannya dengan hasil belajar seseorang. Bagi siswa, minat menjadi faktor untuk dapat mencapai tujuan belajar yang diinginkan. Salah satu masalah yang dihadapi para siswa umumnya adalah rendahnya minat baca. Slameto (2003), menyatakan bahwa minat adalah rasa suka dan ketertarikan pada suatu hal atau aktivitas, tanpa ada yang menyuruh.

${ }^{1}$ Guru Nurul Jadid Probolinggo

${ }^{2}$ Dosen Jurusan Geografi UM

${ }^{3}$ Dosen Jurusan Geografi UM
Minat pada dasarnya adalah penerimaan akan suatu hubungan akan diri sendiri dengan yang ada di luar diri. Misalnya pada kehidupan sehari-hari yaitu seorang siswa yang memiliki minat tinggi terhadap pelajaran geografi maka akan memusatkan perhatian lebih banyak daripada siswa lainnya. Pemusatan perhatian terhadap mata pelajaran tersebut yang memungkinkan siswa untuk mem- 
baca lebih giat dan akan mencapai hasil belajar yang diinginkan.

Minat yang tinggi dalam membaca merupakan salah satu faktor yang turut menentukan keberhasilan membaca. Harjasujana (1988) mengungkapkan bahwa minat yang tinggi terhadap suatu topik akan memberikan energi mental tambahan yang diperlukan dalam upaya menyarikan informasi dari suatu teks, sehingga minat membaca memegang peranan yang penting dalam menunjang keberhasilan membaca. Pengembangan minat dan kebiasaan membaca di sekolah hendaknya menjadi dasar untuk pengembangan intelektual. Guru harus mampu menyadarkan dengan memberikan motivasi dan memberi contoh para siswa agar selalu membina dan meningkatkan kualitas diri melalui kegiatan membaca buku-buku yang berkaitan dengan bidang studi.

Kebiasaan membaca adalah keterampilan yang diperoleh setelah seseorang dilahirkan, bukan keterampilan bawaan. Lebih dari itu, membaca menurut Nadeak (2005) adalah sebuah kegiatan kreatif. Saat membaca, seseorang berdialog dengan dirinya sendiri; dengan tokoh-tokoh yang terkandung di dalam bacaan, saling mengasah intelektualitas dengan pengarang dalam bayang-bayang rasa ingin tahu, terciptanya berpikir kritis untuk meluruskan kegelisahan dan menjaring gagasan baru. Oleh karena itu kebiasaan membaca dapat dipupuk, dibina dan dikembangkan. Namun, biasanya bagi negaranegara berkembang, aktivitas membaca pada umumnya adalah untuk memperoleh manfaat langsung.

Minat dan kebiasaan membaca mempunyai hubungan timbal balik yang sangat erat. Seseorang yang memiliki minat dan perhatian yang tinggi terhadap bacaan tertentu akan selalu meluangkan waktunya untuk membaca, sehingga lama kelamaan akan terbiasa dengan kegiatan tersebut dan pada akhirnya memperoleh pemahaman yang lebih baik dibandingkan dengan orang yang tidak mempunyai minat dan kebiasaan membaca. Oleh karena itu, minat dan kebiasaan membaca harus terjalin dengan erat karena keduanya saling menentukan terbentuk tidaknya hal tersebut (Nurhayatin, 1997). Penelitian ini dilakukan untuk mengetahui bagaimana hubungan minat dan kebiasaan membaca dengan hasil belajar geografi siswa SMA Unggulan Pondok Pesantren Zainul Hasan Genggong Probolinggo.

\section{METODE PENELITIAN}

Penelitian ini merupakan penelitian kuantitatif dengan pendekatan korelasi. Karena tergolong penelitian kuantitatif korelasional, maka akan dicari hubungan dan seberapa signifikan tingkat dari hubungan yang terjadi pada masing-masing variabel. Pada penelitian ini terdapat dua variabel bebas, yaitu minat membaca (X1), kebiasaan membaca (X2) dan satu variabel terikat yaitu hasil belajar siswa (Y). Kedua variabel bebas (X1 dan X2) dihubungkan dengan variabel terikat $(\mathrm{Y})$ dengan pola hubungan; (a) Hubungan secara parsial antara variabel $\mathrm{X} 1$ dengan variabel Y, (b) Hubungan secara parsial antara variabel $\mathrm{X} 2$ dengan variabel $\mathrm{Y}$, dan (3) Hubungan secara simultan antara variabel X1 dan X2 secara bersama-sama dengan variabel $\mathrm{Y}$. 
Kurnia Maulidi Noviantoro, Achmad Amirudin, Budijanto. Hubungan Minat Dan Kebiasaan Membaca Dengan Hasil Belajar Geografi Siswa Sma Unggulan Pondok Pesantren Zainul Hasan Genggong Probolinggo

Populasi yang digunakan dalam penelitian ini adalah kelas X SMA Unggulan Pondok Pesantren Zainul Hasan Genggong Probolinggo tahun ajaran 2015/2016 yang terdiri dari 4 kelas dengan jumlah 91 siswa. Jumlah sampel ditentukan dengan menggunakan teknik Puposive Sampling. Alasan penggunaan teknik tersebut karena untuk mengukur hasil belajar dengan minat dan kebiasaan membaca salah satunya yaitu melalui nilai, sehingga sampelnya ditentukan langsung menunjuk dua kelas yang memiliki nilai rata-rata tertinggi dan terendah untuk nilai mata pelajaran Geografi. Dua kelas tersebut berturut-turut yaitu kelas $\mathrm{X} 3$ yang berjumlah 15 siswa dan kelas $\mathrm{X} 4$ yang berjumlah 19 siswa.

Instrumen yang digunakan dalam penelitian ini adalah angket. Cara menjawab angket yaitu dengan memberikan tanda cek atau centang $(\sqrt{ })$ pada lembar jawaban yang tersedia. Adapun pedoman penyekorannya ditetapkan dengan SL SR $\mathrm{K} \mathbf{J}$ TP dengan masing-masing skor dari 5-1. Variabel dalam penelitian dijabarkan menjadi komponen-komponen yang dapat diukur. Komponen-komponen yang terukur ini kemudian dijabarkan menjadi tolak ukur untuk menyusun item instrumen yang berupa pertanyaan atau pernyataan yang kemudian dijawab oleh responden. Berdasarkan tanggapan responden tersebut, dibuat kriteria penilaian dimana nantinya skor diolah menjadi nilai (bobot) yang akan digunakan sebagai dasar untuk membuat keputusan tentang minat dan kebiasaan yang dimiliki siswa.
Dalam penelitian ini pembuatan kriteria pembobotannya dibagi menjadi 3 yaitu tinggi, sedang, dan rendah. Untuk kriteria yang masuk dalam kategori tinggi mendapat bobot 3, kategori sedang mendapat bobot 2, dan untuk kategori rendah dibobot 1 .

Skor hasil tabulasi angket diolah dengan uji statistik menggunakan program SPSS 16. Data yang dianalisis berupa skor terkoreksi setiap individu dalam sampel penelitian. Analisis data yang bertujuan untuk mengetahui hubungan antara minat dan kebiasaan membaca terhadap hasil belajar geografi berupa uji korelasi dan regresi sederhana dengan taraf signifikansi 0,05 ( $p<0,05)$. Analisis dilanjutkan dengan uji regresi berganda dan menentukan besar koefesien determinasi untuk mengetahui hubungan yang paling dominan di antara minat dan kebiasaan membaca dengan hasil belajar siswa

\section{HASIL PENELITIAN DAN PEMBA- HASAN}

\section{Hubungan antara minat membaca dengan hasil belajar geografi siswa SMA Unggulan Pondok Pesantren Zainul Hasan Genggong Probolinggo}

Hubungan antara minat membaca dengan hasil belajar geografi siswa SMA Unggulan Pondok Pesantren Zainul Hasan Genggong Probolinggo diuji menggunakan uji korelasi sederhana. Hasil uji regresi tersebut dijabarkan pada Tabel 1 di bawah ini. 
Tabel 1. Print Out Analisis Regresi Hubungan antara minat membaca dengan hasil belajar geografi siswa SMA Unggulan Pondok Pesantren Zainul Hasan Genggong Probolinggo

\begin{tabular}{|c|c|c|c|c|}
\hline \multicolumn{5}{|c|}{ Model Summary } \\
\hline Model & $\mathrm{R}$ & R Square & $\begin{array}{l}\text { Adjusted } \\
\text { Square }\end{array}$ & \begin{tabular}{l|l}
$\mathrm{R}$ & $\begin{array}{l}\text { Std. Error of the } \\
\text { Estimate }\end{array}$
\end{tabular} \\
\hline 1 & $.297^{\mathrm{a}}$ & .088 & .059 & 13.40029 \\
\hline
\end{tabular}

a. Predictors: (Constant), Minat Baca

b. Dependent Variable: Hasil Belajar

ANOVA ${ }^{b}$

\begin{tabular}{|l|l|l|l|l|l|l|}
\hline \multicolumn{2}{|l|}{ Model } & Sum of Squares & Df & Mean Square & F & Sig. \\
\hline \multirow{4}{*}{1} & Regression & 554.066 & 1 & 554.066 & 3.086 & $.089^{\mathrm{a}}$ \\
\cline { 2 - 8 } & Residual & 5746.169 & 32 & 179.568 & & \\
\cline { 2 - 7 } & Total & 6300.235 & 33 & & & \\
\hline
\end{tabular}

a. Predictors: (Constant), Minat Baca

b. Dependent Variable: Hasil Belajar

\begin{tabular}{|c|c|c|c|c|c|c|}
\hline \multicolumn{7}{|c|}{ Coefficients $^{\mathrm{a}}$} \\
\hline & & \multicolumn{2}{|c|}{ Unstandardized Coefficients } & $\begin{array}{l}\text { Standardized Co- } \\
\text { efficients }\end{array}$ & \multirow[b]{2}{*}{$\mathrm{t}$} & \multirow[b]{2}{*}{ Sig. } \\
\hline \multicolumn{2}{|c|}{ Model } & B & Std. Error & Beta & & \\
\hline \multirow[t]{2}{*}{1} & (Constant) & 91.252 & 18.736 & & 4.870 & .000 \\
\hline & Minat Baca & -.333 & .190 & -.297 & -1.757 & .089 \\
\hline
\end{tabular}

a. Dependent Variable: Hasil Belajar

Berdasarkan hasil analisis regresi pada tabel Coefficients (a) diketahui bahwa hipotesis penelitian ditolak yang bemakna tidak ada hubungan yang signifikan secara parsial antara variabel bebas (minat baca) dengan variabel terikat (hasil belajar). Persamaan regresi yang terbentuk adalah $(\hat{Y})=91,252-0,333 X_{1}$. De-ngan persamaan regresi tersebut dapat diprediksi hasil belajar geografi siswa untuk masa yang akan datang, yaitu 91,252 jika tidak ada minat membaca. Koefisien regresi untuk variabel minat membaca sebesar -0,333 yang bertanda negatif menyatakan bahwa hubungan yang berlawanan arah, dimana kenaikan minat membaca siswa mengakibatkan penurunan terhadap hasil belajar (nilai) begitu pula sebaliknya.

\section{Hubungan antara kebiasaan membaca dengan hasil belajar geografi siswa SMA Unggulan Pondok Pesantren Zainul Hasan Genggong Probolinggo}

Hubungan antara kebiasaan membaca dengan hasil belajar geografi siswa SMA Unggulan Pondok Pesantren Zainul Hasan Genggong Probolinggo diuji menggunakan uji korelasi sederhana. Hasil uji regresi tersebut dijabarkan pada Tabel 2 di bawah ini. 
Tabel 2. Print Out Analisis Regresi Hubungan antara kebiasaan membaca dengan hasil belajar geografi siswa SMA Unggulan Pondok Pesantren Zainul Hasan Genggong Probolinggo

\begin{tabular}{|l|l|l|l|l|}
\hline Model & $\mathrm{R}$ & R Square & $\begin{array}{l}\text { Adjusted } \\
\text { Square }\end{array}$ & $\begin{array}{l}\text { R } \\
\begin{array}{l}\text { Std. Error of the } \\
\text { Estimate }\end{array}\end{array}$ \\
\hline 1 & $.467^{\mathrm{a}}$ & .218 & .193 & 12.40952 \\
\hline
\end{tabular}

a. Predictors: (Constant), Kebiasaan Membaca

b. Dependent Variable: Hasil Belajar

ANOVA $^{b}$

\begin{tabular}{|l|l|l|l|l|l|l|}
\hline \multicolumn{2}{|l|}{ Model } & Sum of Squares & Df & Mean Square & F & Sig. \\
\hline \multirow{4}{*}{1} & Regression & 1372.359 & 1 & 1372.359 & 8.912 & $.005^{\mathrm{a}}$ \\
\cline { 2 - 8 } & Residual & 4927.877 & 32 & 153.996 & & \\
\cline { 2 - 8 } & Total & 6300.235 & 33 & & & \\
\hline
\end{tabular}

a. Predictors: (Constant), Kebiasaan Membaca

b. Dependent Variable: Hasil Belajar

\begin{tabular}{|c|c|c|c|c|c|c|}
\hline \multicolumn{7}{|c|}{ Coefficients $^{\mathbf{a}}$} \\
\hline & & \multicolumn{2}{|c|}{ Unstandardized Coefficients } & \multirow{2}{*}{\begin{tabular}{|l}
$\begin{array}{l}\text { Standardized Co- } \\
\text { efficients }\end{array}$ \\
Beta \\
\end{tabular}} & \multirow[b]{2}{*}{$\mathrm{t}$} & \multirow[b]{2}{*}{ Sig. } \\
\hline \multicolumn{2}{|c|}{ Model } & $\mathrm{B}$ & Std. Error & & & \\
\hline \multirow[t]{2}{*}{1} & (Constant) & 93.355 & 11.839 & & 7.885 & .000 \\
\hline & Kebiasaan Membaca & -.415 & .139 & -.467 & -2.985 & .005 \\
\hline
\end{tabular}

a. Dependent Variable: Hasil Belajar

Berdasarkan hasil analisis regresi pada table 2 Coefficients (a) diketahui bahwa hipotesis penelitian diterima yang bemakna ada hubungan yang signifikan secara parsial antara variabel bebas (kebiasaan membaca) dengan variabel terikat (hasil belajar). Persamaan regresi yang terbentuk adalah $(\hat{\mathrm{Y}})=93,355-0,415 \mathrm{X}_{2}$. Dengan persamaan regresi tersebut dapat diprediksi hasil belajar geografi siswa untuk masa yang akan datang, yaitu 93,355 jika tidak ada kebiasaan membaca. Koefisien regresi untuk variabel kebiasaan membaca sebesar $-0,415$ yang bertanda negatif menyatakan bahwa hubungan yang berlawanan arah, dimana kenaikan kebiasaan membaca siswa

${ }^{1}$ Guru Nurul Jadid Probolinggo

${ }^{2}$ Dosen Jurusan Geografi UM

${ }^{3}$ Dosen Jurusan Geografi UM mengakibatkan penurunan terhadap hasil belajar (nilai) begitu pula sebaliknya.

Hubungan antara minat membaca dan kebiasaan membaca dengan hasil belajar geografi siswa SMA Unggulan Pondok Pesantren Zainul Hasan Genggong Probolinggo

Secara simultan hubungan antara minat dan kebiasaan membaca dengan hasil belajar geografi siswa SMA Unggulan Pondok Pesantren Zainul Hasan Genggong Probolinggo diuji menggunakan uji korelasi berganda (multiple regression). Hasil uji regresi berganda tersebut dijabarkan pada Tabel 3 di bawah ini. 
Tabel 3. Print Out Analisis Regresi berganda Hubungan antara minat dan kebiasaan membaca dengan hasil belajar geografi siswa SMA Unggulan Pondok Pesantren Zainul Hasan Genggong Probolinggo

\begin{tabular}{|c|c|c|c|c|c|}
\hline \multicolumn{6}{|c|}{ Model Summary } \\
\hline Model & $\mathrm{R}$ & R Square & $\begin{array}{l}\text { Adjusted } \\
\text { Square }\end{array}$ & $\mathrm{R}$ & $\begin{array}{l}\text { Std. Error of the } \\
\text { Estimate }\end{array}$ \\
\hline 1 & $.469^{\mathrm{a}}$ & .220 & .169 & & 12.59358 \\
\hline
\end{tabular}

a. Predictors: (Constant), Kebiasaan Membaca, Minat Baca

b. Dependent Variable: Hasil Belajar

\begin{tabular}{|l|l|l|l|l|l|l|}
\hline \multicolumn{2}{|c|}{ MNOVA $^{\text {b }}$} \\
\hline \multirow{3}{*}{1} & Sum of Squares & df & Mean Square & F & Sig. \\
\cline { 2 - 8 } & Regression & 1383.687 & 2 & 691.844 & 4.362 & $.021^{\mathrm{a}}$ \\
\cline { 2 - 8 } & Residual & 4916.548 & 31 & 158.598 & & \\
\cline { 2 - 7 } & Total & 6300.235 & 33 & & & \\
\hline
\end{tabular}

a. Predictors: (Constant), Kebiasaan Membaca, Minat Baca

b. Dependent Variable: Hasil Belajar

\begin{tabular}{|c|c|c|c|c|c|c|}
\hline \multicolumn{7}{|c|}{ Coefficients $^{\mathrm{a}}$} \\
\hline & & \multicolumn{2}{|c|}{ Unstandardized Coefficients } & \multirow{2}{*}{\begin{tabular}{|l} 
Standardized Co- \\
efficients
\end{tabular}} & \multirow{2}{*}{$\mathrm{t}$} & \multirow[b]{2}{*}{ Sig. } \\
\hline \multicolumn{2}{|c|}{ Model } & B & Std. Error & & & \\
\hline \multirow[t]{3}{*}{1} & (Constant) & 89.911 & 17.618 & & 5.103 & .000 \\
\hline & Minat Baca & .067 & .249 & .059 & .267 & .791 \\
\hline & Kebiasaan Membaca & -.452 & .198 & -.508 & -2.287 & .029 \\
\hline
\end{tabular}

a. Dependent Variable: Hasil Belajar

Berdasarkan hasil analisis regresi pada table $3 \boldsymbol{A N O} \boldsymbol{V A}^{\boldsymbol{b}}$ diketahui bahwa hipotesis penelitian diterima yang bemakna ada hubungan yang signifikan secara simultan antara variabel bebas (minat dan kebiasaan membaca) dengan variabel terikat (hasil belajar). Persamaan regresi yang terbentuk adalah $(\hat{\mathrm{Y}})=$ $89,911+0,067 \mathrm{X}_{1}-0,452 \mathrm{X}_{2}$. Dengan persamaan regresi tersebut dapat diprediksi hasil belajar geografi siswa untuk masa yang akan datang, yaitu 89,911 jika tidak ada minat dan kebiasaan membaca. Koefisien regresi untuk variabel minat

${ }^{1}$ Guru Nurul Jadid Probolinggo

${ }^{2}$ Dosen Jurusan Geografi UM

${ }^{3}$ Dosen Jurusan Geografi UM membaca sebesar 0,067 yang bertanda positif menyatakan bahwa hubungan yang searah, dimana kenaikan/penurunan minat membaca siswa mengakibatkan kenaikan/ penurunan terhadap hasil belajar (nilai). Sedangkan koefisien regresi untuk variabel kebiasaan membaca sebesar -0,452 yang bertanda negatif menyatakan bahwa hubungan yang berlawanan arah, dimana kenaikan kebiasaan membaca siswa mengakibatkan penurunan terhadap hasil belajar (nilai) begitu pula sebaliknya. 
Kurnia Maulidi Noviantoro, Achmad Amirudin, Budijanto. Hubungan Minat Dan Kebiasaan Membaca Dengan Hasil Belajar Geografi Siswa Sma Unggulan Pondok Pesantren Zainul Hasan Genggong Probolinggo

\section{Hubungan yang paling dominan anta- ra minat membaca dan kebiasaan membaca dengan hasil belajar geografi SMA}

Untuk mengetahui hubungan yang paling dominan antara minat dan kebiasaan membaca dengan hasil belajar geografi siswa SMA Unggulan Pondok Pesantren Zainul Hasan Genggong Probolinggo, maka di lihat nilai Koefisien Diterminan (KD). Berdasarkan hasil anali-sis hubungan parsial, dapat diketahui masing-masing nilai Koefisien Diterminannya yaitu: variabel minat membaca memiliki nilai koefisien determinan sebesar $8,8 \%$, artinya minat membaca memberikan sumbangan (kontribusi) terhadap hasil belajar geografi siswa SMA Unggulan Pondok Pesantren Zainul Hasan Genggong Probolinggo sebesar $8,8 \%$. Sedangkan variabel kebiasaan membaca memiliki nilai koefisien determinan sebesar $21,8 \%$, artinya kebiasaan membaca memberikan sumbangan (kontribusi) terhadap hasil belajar geografi siswa SMA Unggulan Pondok Pesantren Zainul Hasan Genggong Probolinggo sebesar 21,8\%. Berdasarkan nilai koefisien tersebut dapat diketahui nilai Koefisien Diterminan yang paling besar ialah kebiasaan membaca. Dengan demikian dapat disimpulkan bahwa hubungan yang paling dominan di antara minat dan kebiasaan membaca dengan hasil belajar geografi siswa SMA Unggulan Pondok Pesantren Zainul Hasan Genggong Probolinggo adalah kebiasaan membaca.

\section{SIMPULAN, SARAN, DAN REK- OMENDASI}

Berdasarkan pada hasil penelitian maka dapat disimpulkan bahwa terdapat hubungan negatif antara minat membaca dengan hasil belajar geografi siswa, dan terdapat hubungan positif antara kebiasaan membaca dengan hasil belajar. Sedangkan secara simultan terdapat hubungan yang positif antara minat dan kebiasaan membaca terhadap hasil belajar geografi. Persentase kontribusi minat membaca dan kebiasaan membaca terhadap hasil belajar geografi secara berturut-turut adalah $8,8 \%$ dan $21,8 \%$. Berdasarkan hasil penelitian, hubungan yang paling dominan di antara minat dan kebiasaan membaca dengan hasil belajar geografi siswa SMA Unggulan Pondok Pesantren Zainul Hasan Genggong Probolinggo adalah kebiasaan membaca.

\section{DAFTAR PUSTAKA}

Evianti, A.P. 2013. Hubungan Kebiasaan Membaca dan Minat Baca Dengan Hasil Belajar Mata Pelajaran Geografi Siswa SMA Laboratorium Universitas Negeri Malang. Jurnal Iти Pendidikan, (online), (http://jurnalonline.um.ac.id) diakses 22 Oktober 2015.

Harjasujana, Ahmad. 1988. Materi Ajar: Proses Membaca. UT: Jakarta.

Latif, M.A. 2015.Hubungan Antara Minat Baca dengan Hasil Belajar Kognitif Pada Pembelajaran Biologi Berbasis Reading Concept MAP TGT dan Berbasis Reading Concept Map NHT. Tesis tidak diterbitkan. Malang: Jurusan Pendidikan Biologi Program Pasca Sarjana Universitas Negeri Malang. 
Nadeak, Wilson. 2005. Membaca, Menulis dan Tradisi. Harian Kompas.

Nurhayatin. 1997. Minat Baca dan Kebiasaan Membaca di Masyarakat Perguruan Tinggi Aksentuasi Perpustakaan dan Pustakawan. Jakarta: IPI DKI.

Riduwan dan Sunarto. 2007. Pengantar Statistika Lengkap Dengan Aplikasi SPSS 16. Bandung: Alfabeta.

Slameto. 2003. Belajar Dan FaktorFaktor Yang Mempengaruhi. Jakarta. Rineka Cipta.
Sugiyono. 2010. Metode Penelitian Kuantitatif, Kualitatif dan R \& D. Bandung: CV Alfabeta.

Wahyuningtyas, Neni. 2012. Hubungan Minat dan Kebiasaan Membaca dengan Prestasi Belajar Mahasiswa Pendidikan Geografi Universitas Negeri Malang. Tesis tidak diterbitkan. Malang: Jurusan Pendidikan Geografi Program Pasca Sarjana Universitas Negeri Malang. 